УДК 347.2

DOI https://doi.org/10.51989/NUL.2021.5.20

\title{
СУДОВА ПРАКТИКА У СПОРАХ ПРО ЗАХИСТ АВТОРСЬКИХ ПРАВ, ЩО ВИНИКАЮТЬ ПРИ ПОРУШЕННІ УМОВ ЛІЦЕНЗІЙНИХ ДОГОВОРІВ
}

\section{Поливач Євген Юійович,}

аспірант кафедри підприємницького та корпоративного права

Київського національного економічного університету імені Вадима Гетьмана

Стаття присвячена висвітленню питання захисту майнових прав творців комп'ютерних програм у судовому порядку в разі порушення умов авторських (ліцензійних) договорів, адже часто трапляються випадки використання комп'ютерних програм фізичними особами, організаціями та підприємствами без ліцензії, усупереч чинному законодавству, яке покликане регулювати відносини між автором і особами, які використовують твір.

Мета наукової роботи полягає у проведенні аналізу сучасного стану захисту й охорони майнових прав автора, його правонаступників на комп'ютерні програми на прикладі судової практики.

Позивачами даної категорії справ є: автори творів, їхні спадкоємці й особи, які набули права на твори відповідно до договору чи закону (суб'єкти авторського права, їхні правонаступники); виконавці творів, їхні спадкоємці й особи, які набули суміжні права відповідно до договору чи закону щодо виконань [10]. Відповідачами є користувачі (набувачі) авторських прав, які використовують твір за ліцензійним договором або авторським договором.

Позивач зобов'язаний довести факт наявності в нього авторського права і суміжних прав, факт порушення його прав відповідачем, розмір шкоди, завданої відповідачем.

Суду варто виходити з наявності матеріально-правової презумпції авторства. Відповідач, який заперечує проти позову, зобов'язаний довести дотримання вимог Закону № 3792-XII під час використання ним об'єкта авторського права і суміжних прав, а також спростувати передбачену цивільним законодавством презумпцію винного завдання шкоди.

Згідно зі статтею 18 Закону України «Про авторське право і суміжні права» та частиною 4 статті 433 Цивільного кодексу України комп'ютерні програми охороняються як літературні твори [3].

Також у судовій практиці, зокрема в постанові Верховного Суду України № 5 від 4 червня 2010 року зазначено, що комп'ютерні програми охороняються як об'єкти авторського права, а саме як літературні твори. Відповідна правова охорона застосовується і до комп'ютерних програм незалежно від способу їх вираження відповідно до норм статті 2 Бернської конвенції про охорону літературних і художніх творів.

Ключові слова: творець, авторське право, судова практика, експертиза, презумпція авторства, ліцензійний договір, ліцензіат, ліцензіар, спори у сфері інтелектуальної власності, захист майнових прав автора.

\section{Polyvach Yevhen. Judicial practice of disputes on copyright protection arising in} the event of violation of the terms of the license agreements

The article is devoted to the issue of protection of property rights of creators of computer programs in court in violation of copyright (license) agreements, because there are often cases of use of computer programs by individuals, organizations and enterprises without a license, contrary to current legislation to regulate relations. between the author and the persons who use the work.

The purpose of this scientific work is to conduct a legal description, analysis of the current state of protection and protection of property rights of the author, his successors in computer programs on the example of case law.

The plaintiffs in this category of cases are: the authors of the works, their heirs and persons who have acquired the rights to the works in accordance with the contract or law (subjects of copyright, their successors); performers of works, their heirs and persons who have acquired related rights in accordance with the contract or the law on performance [10]. Defendants are users (acquirers) of copyright who use the work under a license agreement or copyright agreement. 
The plaintiff is obliged to prove the fact that he has copyright and related rights, the fact of violation of his rights by the defendant, the amount of damage caused by the Defendant.

The court should proceed from the existence of a substantive presumption of authorship. The defendant, who objects to the claim, is obliged to prove compliance with the requirements of Law № 3792-XII when using the object of copyright and related rights, as well as to refute the presumption of guilt caused by civil law.

According to Article 18 of the Law of Ukraine "On Copyright and Related Rights" and part four of Article 433 of the Civil Code of Ukraine, computer programs are protected as literary works [3].

Also in judicial practice, in particular in the Resolution of the Supreme Court of Ukraine № 5 of 04.06.2010 it is stated that computer programs are protected as objects of copyright, namely as literary works. Appropriate legal protection also applies to computer programs, regardless of how they are expressed in accordance with the provisions of Article 2 of the Berne Convention for the Protection of Literary and Artistic Works.

Key words: creator, copyright, litigation, examination, presumption of authorship, license agreement, licensee, licensor, intellectual property disputes, protection of property rights of author.

Кожний громадянин має право на результати своєї інтелектуальної, творчої діяльності; ніхто не може використовувати або поширювати їх без його згоди, за винятками, встановленими законом [1].

В авторів нерідко виникають труднощі в доведенні авторства на комп'ютерні програми. Часто авторство потребує визнання вже на стадії судового розгляду, незважаючи на презумпцію авторства. Нерідко суди доходять висновку, що документом, який засвідчує авторство на оприлюднений чи неоприлюднений твір, а також факт і дату оприлюднення твору, $є$ свідоцтво.

Отже, як автору або правонаступнику довести, що саме йому належить та чи інша комп'ютерна програма?

Ім'я автора комп'ютерної програми може бути відображене у вихідному коді, в аудіовізуальних зображеннях, породжуваних комп'ютерною програмою, у супровідній документації і на упаковці носіїв екземпляра програми [8, с. 6]. У разі відкриття файлу з вихідним кодом можна побачити ім'я автора, за умови його розміщення. Водночас суди не завжди вдаються до таких дій під час розгляду спору. Автори не завжди вказують своє ім'я самим таким способом [12].

Неузгодженим лишається питання щодо технічної можливості автора зазначати своє ім'я на примірнику комп'ютерної програми таким способом, щоб це міг побачити суд під час вирішення спору щодо авторських прав на комп'ютерну програму.

Фізична особа (творець), яка має авторське право, може передати свої майнові права будь-якій іншій особі цілком чи частково. Передача майнових прав автора (чи іншої особи, яка має авторське право) оформляється авторським договором.

Майнові права, що передаються за авторським договором, мають бути в ньому визначені. Майнові права, не зазначені в авторському договорі як відчужувані, уважаються такими, що не передані [3].

Згідно із ч. 4 ст. 433 Цивільного кодексу (далі - ЦК), ст. 18 Закону № 3792-XII, комп'ютерні програми охороняються як об'єкти авторського права, а саме як літературні твори. Така охорона застосовується до комп'ютерних програм незалежно від способу або форми їх вираження.

Авторське право виникає за фактом створення інтелектуальною творчою працею автора або співавторів твору науки, літератури і мистецтва. Твір уважається створеним із моменту первинного надання йому будь-якої об'єктивної форми з урахуванням суті твору (зокрема, письмової форми, електронної форми, речової форми). Якщо не доведено інше, результат інтелектуальної діяльності вважається створеним творчою працею [10].

Творець $\epsilon$ первинним суб'єктом, якому належить авторське право, і саме відповідач повинен доводити протилежне. Позивач також повинен виконувати свій процесуальний обов'язок із доведення факту наявності в нього авторського права, представляти суду примірник твору (зокрема, комп'ютерної програми) із зазначеним ім'ям автора або відповідне свідоцтво про авторство (за його наявності), яке і засвідчує наявність у пози- 
вача авторських прав. Однак наявність зазначеного імені автора на примірнику твору або наявність свідоцтва вже звільняє позивача від необхідності подання інших доказів на підтвердження вказаного факту авторства та дає суду змогу застосувати презумпцію авторства.

Презумпція авторства $€$ законною, поки іiї не спростують, а цей обов'язок покладається на відповідача у справі [12].

Відчуження майнового права на використання твору може здійснюватися на основі авторського договору про передачу виключного права на використання твору або на основі авторського договору про передачу невиключного права на використання твору.

Варто зауважити, що Цивільний кодекс України не містить визначення авторського договору, а Закон «Про авторське право і суміжні права» не містить визначення ліцензійного договору.

За авторським договором про передачу виключного права на використання твору автор (особа, яка володіє виключним авторським правом) передає право використовувати твір окремим способом і у встановлених межах тільки одній особі, якій ці права передаються, і надає цій особі право дозволяти або забороняти таке використання твору іншим особам.

Варто зауважити, що за особою, яка передає виключне право на використання твору, залишається право на використання цього твору лише в частині прав, що не передаються.

За ліцензійним договором в розумінні ст. 1109 ЦК України ліцензіату передаються дозвіл на використання об'єкта інтелектуальної власності, конкретні права на використання об'єкта права інтелектуальної власності, які були чинними на момент укладення договору [2].

Ліцензійний договір можна вважати різновидом авторського договору про передачу невиключного майнового права.

За авторським договором про передачу невиключного права на використання твору автор (творець) передає іншій особі право використовувати твір певним способом і у встановлених межах. За особою, яка передає невиключне право, зберігається право на використання твору і на передачу невиключного права на вико- ристання твору іншим особам [3].

Громадяни України також можуть звертатись по захист порушених прав у сфері інтелектуальної власності до Європейського суду з прав людини. Це підтверджується рішенням суду у справах A.D. v. the Netherlands від 11 січня 1994 р. та Melnychuk v. Ukraine від 5 липня 2005 р., відповідно до яких останній дійшов висновку, що інтелектуальна власність захищається ст. 1 Першого протоколу до Конвенції про захист прав людини і основоположних свобод.

Верховний Суд України у п. 12 постанови Пленуму від 4 червня 2010 р. № 5 «Про застосування судами норм законодавства у справах про захист авторського права і суміжних прав» зазначає, що суду варто виходити з наявності матеріальноправової презумпції авторства [10].

Це означає наявність необхідної доказової бази у сторін, для доведення авторства, захисту прав ліцензіара (автора), його правонаступників.

Тому автор твору $є$ первинним суб'єктом, якому належить авторське право, і саме відповідач повинен доводити протилежне. Позивач також повинен виконувати свій процесуальний обов'язок із доказування факту наявності в нього авторського права, представляти суду примірник твору (зокрема, комп'ютерної програми) із зазначеним ім'ям автора або відповідне свідоцтво про авторство (за його наявності), яке засвідчує наявність у позивача авторських прав. Однак наявність зазначеного імені автора на примірнику твору або наявність свідоцтва вже звільняє позивача від необхідності подання інших доказів на підтвердження вказаного факту авторства та дає суду змогу застосувати презумпцію авторства.

Варто зазначити, що необхідно уникати необґрунтованого зупинення провадження у справі, що призводить до затягування строків її розгляду і перебування у стані невизначеності учасників процесу, що може призвести до порушення положень ч. 1 ст. 6 Конвенції про захист прав людини і основоположних свобод, яка покладає на національні суди обов'язок здійснити швидкий та ефективний розгляд справ упродовж розумного строку.

Такі висновки викладені в постановах 
Верховного Суду від 5 березня 2019 р. у справі № 910/5425/18 та від 20 червня 2019 р. у справі № 910/12694/18.

Згідно з положенням п. 2 ч. 1 ст. 441 ЦК України та п. 8 ч. 3 ст. 15 Закону України «Про авторське право і суміжні права», відтворення творів $\epsilon$ одним зі способів використання творів.

Відповідно до абз. 7 п. 46 постанови Пленуму Вищого господарського суду України № 12 від 17 жовтня 2012 р. «Про деякі питання практики вирішення спорів, пов'язаних із захистом прав інтелектуальної власності» (далі - Постанова № 12 від 17 жовтня 2012 р.), неправомірне зберігання комп'ютерних програм у пам'яті комп'ютера чи іншого електронного обладнання $\epsilon$ порушенням майнового авторського права.

Згідно 3 п. 51.2 постанови Пленуму Вищого господарського суду України № 12 від 17 жовтня 2012 р., у разі судового спору, у якому підлягають з'ясуванню обставини щодо похідного характеру комп'ютерної програми, незаконного використання подібної комп'ютерної програми, права на яку належать позивачеві, належним та допустимим доказом буде висновок експерта, оскільки суд не володіє спеціальними технічними знаннями в цій сфері, тому не може надати відповідну оцінку таким обставинам справи [8].

Орієнтовний перелік питань, які можуть бути поставлені експерту для роз'яснення щодо внесення змін, модифікації комп'ютерної програми з метою забезпечення її функціонування на технічних засобах, визначено Науковометодичними рекомендаціями 3 питань підготовки та призначення судових експертиз та експертних досліджень, затвердженими наказом Міністерства юстиції України від 8 жовтня 1998 р. № 53/5 (у редакції наказу Міністерства юстиції України від 26 грудня 2012 р. № 1950/5) [6, с. 399].

Первинним суб'єктом, якому належить авторське право, є автор твору. За відсутності доказів іншого автором твору вважається особа, зазначена як автор на оригіналі або примірнику твору (презумпція авторства).

Це положення застосовується також у разі опублікування твору під псевдоні- мом, який ідентифікує автора.

Процесуальний обов'язок доказування для творця в разі порушення його прав полягає в тому, що він передусім як позивач повинен довести належність йому авторського права (зокрема, що спірний об'єкт належить до об'єктів авторського права) та права на його захист. Під час вирішення цієї категорії справ треба пам'ятати про законодавчу презумпцію авторства, яку суди повинні застосовувати, поки відповідач не доведе протилежного належними та допустимими доказами.

Верховний Суд України в п. 12 постанови Пленуму від 4 червня 2010 р. № 5 «Про застосування судами норм законодавства у справах про захист авторського права і суміжних прав» звернув увагу на те, що суду варто виходити з наявності матеріально-правової презумпції авторства [10].

Основними доказами під час розгляду кримінальних справ у сфері інтелектуальної власності, якими користуються суди під час винесення обвинувальних вироків, $\epsilon$ висновки комп'ютерно-технічної, судовоекономічної експертизи, а також речові докази, які вилучаються під час санкціонованих обшуків правоохоронними органами в рамках досудового розслідування. До таких речових доказів зазвичай відносять технічне комп'ютерне обладнання [9].

Право на переробку, зміну твору як один із способів використання результату інтелектуальної діяльності може бути передано за ліцензійним (авторським) договором.

Окремим випадком переробки твору $\epsilon$ модифікація комп'ютерної програми, тобто будь-які їі зміни, зокрема й переклад з однієї мови програмування іншою [3].

Особа, яка правомірно володіє правомірно виготовленим примірником комп'ютерної програми, має право без згоди автора або іншої особи, яка має авторське право на цю програму, внести до комп'ютерної програми зміни (модифікації) з метою забезпечення ії функціонування на технічних засобах особи, яка використовує ці програми, та вчинити інші дії, установлені імперативною нормою ст. 24 Закону України «Про авторське право і суміжні права».

Вирішення питання про те, чи відбулося 
використання спірного твору без спеціального дозволу (ліцензійного договору) шляхом його відтворення (повністю або частково), чи мало місце створення похідного твору як самостійного об'єкта авторського права може потребувати спеціальних знань, а отже, призначення судової експертизи [8].

Ст. 50 Закону «Про авторське право і суміжні права» встановлює, що вчинення будь-якою особою дій, які порушують особисті немайнові права суб'єктів авторського права, визначені ст. 14 Закону, та їхні майнові права, визначені ст. 15 Закону, $\epsilon$ підставою для судового захисту [7].

3 постанови Пленуму ВСУ «Про застосування судами норм законодавства у справах про захист авторського права і суміжних прав» від 4 червня 2010 р. можна зробити висновок, що належним відповідачем у справі про захист авторського права $\epsilon$ особа, яка своїми діями порушила особисті немайнові чи майнові права суб'єктів авторського права [10].

Авторство на комп'ютерну програму встановлюється на підставі презумпції авторства. Первинним суб'єктом авторського права $\epsilon$ автор програми.

Водночас в авторів нерідко виникають труднощі в доведенні авторства на комп'ютерні програми. Зокрема, ПрАТ «Лізинг інформаційних технологій» та ОСОБА_1 звернулися до суду із заявою про забезпечення позову до подання позовної заяви, мотивуючи це тим, що їм належать майнові авторські права на комп'ютерну програму «Конфігурація IC:LeaseIT" та базу даних "1C:LeaseIT", а відповідач своїми діями порушує їхні авторські права [4, с. 286].

Суд відмовив у задоволенні такої заяви, вказав, що позивачі не довели авторства на вказані об'єкти. Суд в ухвалі послався на презумпцію авторства, вказавши, що автор у будь-який час протягом строку охорони авторського права може зареєструвати своє авторське право у відповідних державних реєстрах [11].

Тобто Суд дійшов висновку, що документом, який засвідчує авторство на оприлюднений чи неоприлюднений твір, а також факт і дату оприлюднення твору, $\epsilon$ свідоцтво. А тому в даному разі від- сутні належні та допустимі докази, які 6 свідчили про те, що позивач $€$ автором комп'ютерної програми «Конфігурація 1C:LeaseIT" та бази даних "1C:LeaseIT" [4, c. 287].

Часто неузгодженим $є$ питання фіксації авторства на комп'ютерну програму. Тому суди відмовляють авторам у вжитті заходів забезпечення позову, мотивуючи це відсутністю доказів авторства і неможливістю застосувати презумпцію авторства. Згідно із презумпцією авторства автором твору (у даному разі - комп'ютерної програми) уважається особа, зазначена як автор на оригіналі або примірнику твору, тому виникає питання: яким чином зазначити ім'я автора на примірнику комп'ютерної програми, щоб це могла побачити будь-яка особа, зокрема й суд, який розглядає спір.

Комп'ютерна програма може бути створена у співавторстві. У такому разі відносини між співавторами можуть бути врегульовані договором між ними про порядок здійснення майнових прав інтелектуальної власності на програму.

У разі відсутності такого договору авторське право на твір здійснюється всіма співавторами спільно.

Важливо, що на комп'ютерну програму поширюються презумпція авторства, відповідно до якої автором та первинним суб'єктом твору вважається особа, що вказана на примірнику комп'ютерної програми, доки інша особа не доведе протилежного [4, с. 286].

Нерідко авторські твори створюються колективами творців програмістів у співавторстві. У такому разі відносини між співавторами можуть бути врегульовані договором між ними про порядок здійснення майнових прав інтелектуальної власності на програму. За відсутності такого договору авторське право на твір здійснюється всіма співавторами спільно.

Як приклад можна навести цивільну справу № № 2609/17205/12, яка вирішувалася Солом'янським районним судом міста Києва та $є$ в загальному доступі на сайті «Судова влада» [5].

У вересні 2011 р. позивачі звернулися з позовом, у якому просили визнати їх співавторами твору «ІНФОРМАЦІЯ_1», припинити дії, що порушують їхнє авторське 
право, шляхом заборони відповідачам учиняти дії щодо розпорядження майновими авторськими правами без згоди позивачів як співавторів, зобов'язати Державну службу інтелектуальної власності України внести до Державного реєстру свідоцтв про реєстрацію авторського права на твір відомості щодо визнання реєстрації за свідоцтвом № HOMEP_1 недійсною.

В обґрунтування заявлених позовних вимог позивачі зазначають, що вказана комп'ютерна програма $\epsilon$ похідним твором від цілої низки програм, що створювались протягом 40 років різними авторами, незмінним автором яких та науковим керівником усіх програм сімейства «ІНФОРМАЦІЯ_10» був $і \in$ ОСОБА_2.

Доводи позивачів про те, що комп'ютерну програму «ПК «ІНФОРМАЦІЯ_1»» не можна вважати службовим твором, оскільки частина співавторів перебувають із відповідачем-1 у трудових відносинах, а частина співавторів не перебувають, суд уважає необґрунтованими, тому що позивачами не подано доказів існування між позивачами та відповідачем-1 цивільно-правових договорів, на підставі яких можна зробити висновок щодо співавторства позивачів [7].

Згідно $з$ п. 6 ст. 2 Конвенції твори, зокрема й комп'ютерні програми, підляумовах авторського договору [5]. гають охороні в усіх країнах Союзу. Ця охорона здійснюється на користь автора і його правонаступників.

За ч. ч. 1, 2 ст. 11 Закону України «Про авторське право і суміжні права» від 23 грудня 1993 р. № 3792-XII, з подальшими змінами і доповненнями, первинним суб'єктом, якому належить авторське право, $€$ автор твору або, за відсутності доказів іншого, автором твору вважається особа, зазначена як автор на оригіналі або примірнику твору (презумпція авторства).

Згідно зі ст. 435 ЦК України та ст. 7, п. 1 ст. 15 Закону України «Про авторське право і суміжні права», суб'єктами авторського права, окрім авторів творів, $\epsilon$ їхні спадкоємці й інші фізичні та юридичні особи, які набули авторських прав відповідно до закону або договору.

Ліцензія на використання об'єкта права інтелектуальної власності може бути оформлена як окремий документ або бути складовою частиною ліцензійного договору між ліцензіаром та ліцензіатом, за яким передаються конкретні права, які $€$ чинними на момент укладення договору [2].

Розробники програмного забезпечення - фізичні особи можуть надати юридичній особі виключну ліцензію на використання програмного забезпечення на

\section{ЛITЕРАТУРА:}

1. Конституція України : Закон України від 28 червня 1996 р. № 254к/96-ВР / Верховна Рада України. Відомості Верховної Ради України. 1996. № 30. Ст. 141.

2. Цивільний кодекс України. Відомості Верховної Ради України. 2003. № № 40-44. 356 с.

3. Про авторське право і суміжні права : Закон України № 3792-XII від 23 грудня 1993 р. Відомості Верховної Ради України. 1994. № 13. 64 с.

4. IT право / за ред. О. Яворської. Львів : Левада, 2017. 470 с.

5. Ромащенко Д. Судова практика. Ліцензійні відносини. Юрист і Закон. 2018. № 14. URL: http://surl.li/ahaue (дата звернення: 17.09.2021).

6. Посібник для суддів з інтелектуальної власності / І. Бенедисюк та ін. Київ : К.І.С., 2018. $424 \mathrm{c}$.

7. Рішення Солом'янського районного суду міста Києва у справі № 2609/17205/12 від 21 березня 2014 p. URL: https://reyestr.court.gov.ua/Review/37883157 (дата звернення: 17.09.2021).

8. Про деякі питання практики вирішення спорів, пов'язаних із захистом прав інтелектуальної власності : постанова Вищого господарського суду України № 12 від 17 жовтня 2012 р. URL: https://zakon.rada.gov.ua/laws/show/v0012600-12\#Text (дата звернення:17.09.2021).

9. Судова практика вирішення спорів, пов'язаних із неправомірним використанням об'єктів авторського права і суміжних прав в мережі Інтернет URL: http://surl.li/ahaty (дата звернення:17.09.2021). 
10. Про застосування судами норм законодавства у справах про захист авторського права і суміжних прав : постанова Верховного Суду України № 5 від 4 червня 2010 p. URL: https://zakon.rada.gov.ua/laws/show/v0005700-10\#Text (дата звернення:17.09.2021).

11. Тарасенко Л. Комп'ютерна програма як об'єкт інтелектуального права. URL: http://aphd.ua/publication-167/ (дата звернення: 17.09.2021). 